University of Wollongong

Research Online

Faculty of Social Sciences - Papers (Archive) Faculty of Arts, Social Sciences \& Humanities

2013

While we are talking about environmental justice, let's give children a voice

Peter Andersen

University of Wollongong, petera@uow.edu.au

Follow this and additional works at: https://ro.uow.edu.au/sspapers

Part of the Education Commons, and the Social and Behavioral Sciences Commons

Research Online is the open access institutional repository for the University of Wollongong. For further information contact the UOW Library: research-pubs@uow.edu.au 


\title{
While we are talking about environmental justice, let's give children a voice
}

\begin{abstract}
As governments, communities and individuals grapple with how to deal with the avalanche of negative news regarding the environment, children are often left out of the decision-making processes. Traditional Western schooling is still dominated by the 'banking' method of teaching, in which knowledge is deposited into the minds of the children under an adult-centric educational paradigm. As a step toward achieving justice for children, educators need to reverse the traditional model of intergenerational influence by furnishing children with the chances, tools and skills to influence those around them, including adults, to live more sustainable lives. This chapter will highlight the plight of children in Western society and the findings of a research project conducted as part of a doctoral thesis, titled, 'Children as environmental change agents: using a shared protocol to bring about or support environmentally responsible behaviour in the family home.' Analysed through the lens of a critical researcher, the data reveals a number of key findings; children can indeed be environmental change agents, capable of leading their families, schools and communities toward a more sustainable future; however, the road to justice for children is a complex one, with many societal forces to be contended with along the way.
\end{abstract}

\section{Keywords}

about, talking, we, while, justice, give, let, children, environmental, voice

Disciplines

Education | Social and Behavioral Sciences

\section{Publication Details}

Andersen, P. (2013). While we are talking about environmental justice, let's give children a voice. In K. Druffel (Eds.), Looking Within: Finding an Environmental Justice and Global Citizenship Lens (pp.

103-113). Oxford, United Kingdom: Inter-Disciplinary Press. 


\title{
While we are talking about environmental justice, let's give children a voice
}

\author{
Peter Andersen
}

\begin{abstract}
As governments, communities and individuals grapple with how to deal with the avalanche of negative news regarding the environment, children are often left out of the decision-making processes. Traditional Western schooling is still dominated by the 'banking' method of teaching, in which knowledge is deposited into the minds of the children under an adult-centric educational paradigm. As a step toward achieving justice for children, educators need to reverse the traditional model of intergenerational influence by furnishing children with the chances, tools and skills to influence those around them, including adults, to live more sustainable lives. This paper will highlight the plight of children in Western society and the findings of a research project conducted as part of a doctoral thesis, titled, 'Children as environmental change agents: using a shared protocol to bring about or support environmentally responsible behaviour in the family home'. Analysed through the lens of a critical researcher, the data reveals a number of key findings; children can indeed be environmental change agents, capable of leading their families, schools and communities toward a more sustainable future; however, the road to justice for children is a complex one, with many societal forces to be contended with along the way.
\end{abstract}

Key Words: Critical research, environmental activism, environmental change agents, education, intergenerational influence.

$* * * * *$

\section{Taking the step to environmental activism: offering children an opportunity}

In 2006, I spoke at a school assembly in the small boarding school in which I was teaching, in the Cotswolds, England. While, in my role as the Senior Master, it was not uncommon for me to address the school community, however, on this occasion I stood before them as an environmental activist, inviting students from the school who had heard enough negative news about the plight of the environment, to join a group to do just that; to do something about it. For many years, only my wife and close friends knew of my passion to protect the environment, and that assembly marked a turning point in my life as I changed from Peter Andersen, English teacher, to Peter Andersen, environmental educator. My rationale was simple; children are told or hear about important social issues, and are often dictated to by adults on what they should do or how they should 
respond to these issues. Rarely are they provided with opportunities to share the decision-making with adults, or take the lead in ventures to improve the quality of their communities. Twelve of the students came forward to join, and over the next two years succeeded in bringing about significant changes to the environmental practices and policies of their school. What struck me most powerfully, however, was their desire to transfer their passion for the environment beyond the walls of the school into their family homes. Consequently, we decided to design a Protocol - or contract - to co-sign with their parents and family members on ways to live more sustainably, however, I returned to Australia before seeing this come to fruition. Nevertheless, this concept of intergenerational change-agentry was to become the backbone of the research behind the doctoral thesis that I commenced in 2008, and has remained at the forefront of my teaching pedagogy since.

\section{Children as environmental change agents: using a shared protocol to bring about or support environmentally responsible behaviour in the family home}

I conducted a case study involving six fourteen-year-old children who were given the opportunity to be intergenerational environmental change agents, designing a Protocol which they implemented in their family homes, negotiating with and co-signing with their family members to a more sustainable way of living. Over a period of three months I monitored the efficacy levels of the children as they attempted to adopt the roles of environmental change agents within their family homes. Personal interviews were conducted with the participants after the design phase of the Protocol; prior to the implementation of the Protocols in the family homes; after the negotiation and signing of the Protocols; and after three months of living under the conditions of the Protocol. The results emphatically confirmed my fears that children are buffeted by adult-centric forces in their homes and schools, while also providing hopeful insights into ways forward for children in the field of environmental activism.

Denzin and Lincoln ${ }^{\frac{1}{}}$ claim that there is an 'invisible empire that leaves even more children behind, ${ }^{, 2}$ and it was my hope that my doctoral research project might shed some light on this empire. The project was framed by Critical Theory, underpinned by my belief that children are the victims of immense injustice at the hands of adults, rarely invited to share with them in the decision-making processes on how to cope with the impacts of environmental degradation. My project aimed at 'criticizing social reality, emancipating people, empowering them to change social reality by suggesting possible solutions and thus liberating them from the oppressive and exploitative social structures., ${ }_{-}$The inquiry was completed "with" others rather than "on" or "to”" others, positioning the participants as active collaborators, ${ }^{4}$ which is fundamental to the beliefs of the critical researcher. Kincheloe, McLaren and Steinberg_assert that in order to be considered critical 
research, the aim of the research must be transformation and emancipation: two attributes that marked this project. ${ }^{-}$I was seeking to transform the lives of the children who volunteered to participate in the project, bravely taking on the roles of environmental change agents in their family homes. In transforming their lives, I also hoped to identify the social, familial and educational forces that might be suppressing them. The findings paint a grim picture, highlighting forces that are disempowering for children, but at the same time, outline a way forward for environmental educators looking to empower their students to be environmental change agents.

\section{Transforming themselves: children willing to be environmental change agents}

For a long time there have been calls to position children as political actors, being heard on such important social issues as how to care for the environment. In 1989, the United Nations International Children's Emergence Fund's (UNICEF) Convention on the Rights of the Child formalised the demand on governments and organisations to allow children to take part in political processes that had a bearing on their future well-being. ${ }^{6}$ Coupled with this, the philosophy known as the 'New Sociology of Childhood' has taken root, nurturing the belief that children are agentic, capable of participating with adults to create a better world for them and those that follow. ${ }^{-}$Despite this, however, in the cold reality of the real world, there was still a question mark over whether the students that I approached to participate in the project would have the courage or inclination to do so. What was remarkable was that children did volunteer for the project, and did so knowing that it would potentially have a significant impact on their personal lives and that of their family members over a period of three months. Despite having no previous experience of environmental activism, they still embraced the opportunity to transform themselves into environmental change agents. From this, the question that needs to be asked is why have the students not experienced environmental activism prior to this point in their lives, given that education has been heralded as the major conveyor of knowledge on the plight of the environment?

\section{To be or not to be environmental change agents: the negative role of education}

Despite the publicity on the importance of education in being able to not only educate children about the plight of the environment, but to empower them to take action on this knowledge, the data has revealed clearly that in this case study, education has not had a significantly positive effect on the efficacy of the children as environmental activists. Remarkably, none of the children mentioned that school had provided them with opportunities to actually do anything positive to help the environment, let alone lead projects designed to support the environment. This cuts to the heart of the question of whether, in the field of environmental activism, 
children are being treated justly. Logic would tell me that providing children with the knowledge of a problem and not opportunities to act to solve that problem is unjust. For despite the calls by the researchers and educators to create systems that allow children to actively participate in decision-making around issues relevant to them, this case study confirms Zhao's observation that schools are capable of doing the opposite, and systematically undermining children's agency. ${ }^{-}$Breiting and Wickenberg insist that educators need to press children to analyse how human decision-making processes impact on the environment, ${ }^{9}$ yet for the children in this project, there appeared to be very little connection between what they had learnt at school and their understanding of the plight of the environment. Instead, Freire's assertion that schools operate on the Banking System,,$^{10}$ in which knowledge is deposited into them like money into accounts, often resulting in the inability of the students to act on the knowledge that they have acquired resonates more loudly with the words of the students in this project. ${ }^{11}$ More poignantly, evidence of what McLaren calls emancipatory knowledge, ${ }^{12}$ in which the students develop an understanding of their social relations in terms to power and privilege, failed to emerge through the words of the students. Undoubtedly, the students participating in this project had developed knowledge about the plight of the environment at school, however, it is clear that school had not provided them with opportunities to pursue action competence $2_{2}^{\frac{13}{3}}$ in which they were encouraged to make sense of their impact on the world around them and then more importantly, act on these insights.

With this in mind, it would appear that the students in this project were given a unique opportunity to adopt leadership roles, however, this is only the first step, and what took place once they had taken the lead in their family homes, reveals more insights into the injustice that underpins their lives.

\section{Familial hegemony: dampening the efficacy of young environmental change agents}

By signing up to this project, the children = as I did when stepping out to speak to at the school assembly four years earlier - set about changing their identities, as well as embarking on a voyage that would ultimately test their efficacy under these new personas. In all groups or organisations hegemony exists, and so it is with families. This project's data offered insights into the happenings, in what Payne calls the household moral spaces, and in doing so underlined the hegemonic forces that buffet children while living within these spaces. $\frac{14}{}$ Adorno and Horkheimer argue that ideological hegemony is mediated through such social institutions as the family, and the data underlines the parents' role in perpetuating this hegemony. $\frac{15}{{ }^{15}}$ It reveals the negative impact on the children's efficacy of overwhelming parental power, and the self-perpetuating effect of parents' lack of confidence in their child's efficacy. 
Bauman's_claim that morality begins at home and that the home is an incubator and greenhouse is corroborated by this research project. ${ }^{16}$ The children's ability to convert leadership goals into efficacy were directly influenced by the makeup of the greenhouse - or home in which they live. The introduction of the Protocol into this family domain heralded massive changes for all involved. As in most family homes, the power lies in the hands of the parents and as 'gate keepers' of the familial culture, ${ }^{17}$ their ability to embrace the rapid changes in the family structure forced by the new role of their child, was being tested by the introduction of the Protocol. What stands out from the data is that once the decision to become environmental activists was made, and the parents had agreed to allow the transformation to take place, most of the children still faced stiff opposition from the parents in relation to managing the operation of the Protocols. In two thirds of the families, the parents wrestled control of the implementation and maintenance of the Protocol from their children, and in these cases the family members recorded the lowest scores in relation to how successfully they were transfer to more sustainable practices within their family homes. What stood out was the sceptism that most parents held towards their adolescent children: they simply did not believe that they were genuine in their wish to live more sustainable lives.

Compounding this parental hegemony, Watson argues that individuals live under the spikes of the mega machine, $\frac{18}{-}$ unable to resist the strong tide of influence that propels them toward less-sustainable practices. $\stackrel{19}{-}^{-19}$ key element of this paradigm was the belief on the part of most of the parents that no matter what positive actions they took to change their behaviour, it was still not enough to bring about significant change at a global level. They had effectively been paralysed_by the bad news that had pervaded their homes through the media..$^{20}$ The impact of this once again meant that they were far less receptive to the pleas of their children to follow their lead.

\section{Critical Pedagogy: transformative rather than regurgative knowledge}

In order to truly provide justice for children, educators need to promote the concept of transformational knowledge, which leads children to a state of 'enlightenment'. ${ }^{21},{ }^{22},{ }^{23},{ }^{24},{ }^{25},{ }^{26}$ Through this system, children can develop a desire for universal justice based on an understanding of the hegemonic power structures around them that subvert truth and equality. There are several possibilities for educators: firstly, there is the use of values-based pedagogy, and secondly, the development of action competence as a worthy goal to attain in classrooms.

Levy propounds that schools need to incorporate active values education into the curriculum. ${ }^{27}$ Fien supports this point of view, claiming that students need to embrace the value of compassion as they question the world around them, looking 
for a means of dealing with the social issues that face them. ${ }^{28}$ What is absolutely necessary is that the teachers sustain an ongoing explicit focus on this approach, helping the students to establish interrelationships between fragmentary pieces of information, such as pollution and health of the eco-system, arriving at an understanding of their world as an integrated whole $\mathrm{e}^{\underline{\underline{29}}}$. The most positive aspect of this approach is that these critical evaluations of the world around them have currency within the walls of their classroom, communities and homes. For example, the value of compassion has no borders, and helps teachers students to build understandings around not only scientific, factual accounts of the plight of the environment, but also the subsequent environmental justice issues relating to minority groups in society and endangered animal species. Children are often the victims of hegemonic forces within the field of education and family contexts, and if future teachers underpinned their pedagogical paradigms with values such as compassion and social justice, such power balances would stand a greater chance of being overturned in the classrooms of tomorrow. If parents held these values closer to their hearts, a similar shift away from the familialisation of children might also occur.

The concept of action competence is steeped in critical theory, fighting against violence and oppression, linked to the radical version of 'Bildung'; the formation of the person through education. $\frac{30}{}$ 'It has its aim the fulfillment of humanity: the full development of the capacities and powers of each human individual to question preconceived opinions, prejudices, and "given facts", and the intentioned participation in the shaping of ones' own and joint living conditions'. ${ }^{31}$ In order to foster this development of action competence in schools, teachers need to move away from the dominance of environmental knowledge dissemination in their classrooms - which seems to have had very little impact on the attitudes of the participants in this research project, and which does not necessarily lead to proenvironmental behaviour ${ }^{32}$ - and move towards the fostering of positive environmental attitudes and values. $\frac{33}{}$ This means that teachers need to realign their pedagogical compasses to target the promulgation of transformative knowledge that inevitably leads to action. Jensen proposes four different dimensions of knowledge that can lead to action: knowledge about the nature and extent of the environmental issues; knowledge about the underlying social, political and economic structures and how they contribute to the issue; knowledge about how to affect change; and knowledge about the direction of such change, through the construction of a vision of the world in which they want to live. $\frac{34}{5}$ Schools in the future need to deliberately lead their students towards development of knowledge that will enable them to understand the challenges of bringing about change, and the types of action that are possible for them to attain within their fields of contact. The students in this research project certainly revealed that they had not had the time to develop a vision for their homes that was supported by an understanding of 
the challenges that they might face as they attempted to reach efficacy in their quest to become environmental activists.

\section{Conclusion}

One of the greatest injustices facing humankind is the systematic disempowerment of children. Despite calls from the highest levels to allow children to share in the decision-making processes around important social issues such as environmentalism, this project shows that we have a long way to go. Children are keen to be involved, but are not being provided sufficient opportunities to take action on these issues, while for those that are furnished with these chances, hegemonic forces that dominate their schools and family homes have a disempowering effect on them. In order to restore justice for children, educators need to embrace Critical Pedagogy. In doing so, they can open the eyes of their students to the powerful forces that rule their lives, while more importantly, providing them with the skills to thrive within these domains.

\section{Notes}

1 Norman K. Denzin and Yvonna S. Lincoln, 'Paradigms and Perspectives in Contention', in SAGE Handbook of Qualitative Research, ed. Norman K. Denzin, and Yvonna S. Lincoln (Thousand Oaks: SAGE Publications, 2011), 91-5. 2 Ibid. 93

3 Sotirios Sarantakos, Social Research (South Melbourne: Macmillan Education Australia, 1993), 17.

4 John W. Creswell, Qualitative Inquiry and Research Design (Thousand Oaks: SAGE Publications, 2007).

5 Joe L. Kincheloe, Peter McLaren, and Shirley R. Steinberg, 'Critical Pedagogy, and Qualitative Research: Moving to the Bricolage', in SAGE Handbook of Qualitative Research, ed. Norman K. Denzin, and Yvonna S. Lincoln (Thousand Oaks: SAGE Publications, 2011), 163-77.

6 UNICEF, 'Convention on the Rights of the Child', last modified 29 November 2005, Viewed 28 September 2008, <http://www.unicef.org/crc/index_30167.html>.

7 Reesa Sorin, 'Examining Childhood Through Empowering Lenses', Every Child 15, no. 3 (2009): 34-5.

8 Guoping Zhao, 'The Modern Construction of Childhood: What Does It Do to the Paradox of Modernity?', Studies in Philosophy and Education 30, no. 3 (2011): 241-56.

9 Soren Breiting, and Per Wickenberg, 'The Progressive Development of Environmental Education in Sweden and Denmark', Environmental Educational Research 16, no. 1 (2010): 9-37.

10 Paulo Freire, 'From Pedagogy of the Oppressed', in Critical Pedagogy Reader, ed. Antonio Darder, Marta Baltodano, and Rodolfo D. Torres (New York: RoutledgeFalmer), 2003, 57-68.

11 Bjarne B. Jensen, and Karsten Schnack, 'The Action Competence Approach in Environmental Education', Environmental Education Research 12, no. 3-4 (2006): 471-86.

12 Peter McLaren, Life in Schools. An Introduction to Critical Pedagogy in the Foundations of Education (Boston: Allyn \& Bacon, 2003).

13 Jensen and Schnak, 'Action Competence Approach' 


\section{While we are talking about environmental justice: let's give children a voice}

14 Phillip G. Payne, 'Moral Spaces, the Struggle for an Intergenerational Environmental Ethics and the Social Ecology of Families: An “Other” Form of Environmental Education', Environmental Education Research 16, no. 2 (2010): $209-31$. 15 1972, cited in Henry A. Giroux, 'Critical Theory and Educational Practice', in Critical Pedagogy Reader, ed. Antonio Darder, Marta Baltodano, and Rodolfo D. Torres (New York: RoutledgeFalmer, 2003), 27-56.

16 1997, cited in Payne, 'Moral Spaces'

17 Christine Cawsey, 'There's a Freeway at the Bottom of the Garden', Australian Educational Leader 31, no. 2 (2009): 10-12. 18 David H. Watson, 'Deep Ecology \& Environmental Philosophy: On the Ethics of Crisis and the Crisis in Ethics', in Against the Megamachine: Essays on Empire \& its Enemies, ed. David H. Watson (Brooklyn: Autonomedia, 1997), $224-43$.

19 Horkheimer, cited in Raymond A. Morrow, and Carlos A. Torres, Social Theory and Education: A Critique of Theories of Social and Cultural Reproduction (Albany: State University of New York, 1995).

20 Bjarne B. Jensen, 'Knowledge, Action and Pro-environmental Behaviour', Environmental Education Research 8, no. 3 (2002): 325-34.

21 Wayne, W. Au, and Michael, W. Apple, 'Freire, Critical Education, and the Environmental Crisis', Educational Policy 21, no. 3 (2007): 457-70.

22 Denzin, and Lincoln, 'Paradigms and Perspectives'

23 Giroux, 'Critical Theory'

24 McLaren, Life in Schools

25 Peter, L. McLaren, and James, M. Giarelli, Introduction to Critical Theory and Educational Research, ed. Peter L. McLaren \& James M. Giarelli (Albany: State University of New York Press, 1995), 1-22.

26 Finn Morgensen, and Karsten Schnack, 'The Action Competence Approach and the "New" Discourses of Education for Sustainable Development, Competence and Quality Criteria’, Environmental Education Research 16, no. 1 (2009): 59-74.

27 Josh Levy, 'Are You Making a Difference? Values Education for Real Community Change’, Teacher 186, Nov. (2007): 447.

28 John Fien, 'Learning to Care: Education and Compassion’, Australian Journal of Environmental Education 19 (2003): 1-13. 29 Elaine Lewis, Caroline Mansfield, and Catherine Baudains, 'Getting Down and Dirty: Values in Education for

Sustainability', Issues in Educational Research 18, no. 2 (2008): 138-55.

30 Morgensen, and Schnack, 'Action Competence Approach'

31 Ibid., 61

32 Kempton et al., 1995, cited in Jensen, 'Knowledge, Action'

33 Cutter-Mackenzie and Smith, cited in Sally Birdsall, 'Empowering Students to Act: Learning About, Through and From the Nature of Action', Australian Journal of Environmental Education 26 (2010): 65-84.

34 Jensen, 'Knowledge, Action' 


\section{Bibliography}

Au, Wayne W., and Apple, Michael W. 'Freire, Critical Education, and the Environmental Crisis'. Educational Policy 21, no. 3 (2007): 457-70.

Birdsall, Sally. 'Empowering Students to Act: Learning About, Through and From the Nature of Action'. Australian Journal of Environmental Education 26 (2010): 65-84.

Breiting, Soren, and Wickenberg, Per. 'The Progressive Development of Environmental Education in Sweden and Denmark'. Environmental Educational Research 16, no. 1 (2010): 9-37.

Cawsey, Christine. 'There's a Freeway at the Bottom of the Garden'. Australian Educational Leader 31, no. 2 (2009): 10-12.

Creswell, John W. Qualitative Inquiry and Research Design. Thousand Oaks:

SAGE Publications, 2007.

Denzin, Norman K., and Lincoln, Yvonna S. 'Paradigms and Perspectives in Contention'. In The SAGE Handbook of Qualitative Research, edited by Norman K. Denzin, and Yvonna S. Lincoln, 91-5. 4th ed. Thousand Oaks: SAGE Publications, 2011.

Fien, John. 'Learning to Care: Education and Compassion'. Australian Journal of Environmental Education 19 (2003): 1-13.

Freire, Paulo. 'From Pedagogy of the Oppressed'. In The Critical Pedagogy Reader, edited by Antonio Darder, Marta Baltodano, and Rodolfo D. Torres, 57-68. New York: RoutledgeFalmer, 2003.

Giroux, Henry A. 'Critical Theory and Educational Practice'. In The Critical Pedagogy Reader, edited by Antonio Darder, Marta Baltodano, and Rodolfo D. Torres, 27-56. New York: RoutledgeFalmer, 2003.

Jensen, Bjarne B. 'Knowledge, Action and Pro-environmental Behaviour'. Environmental Education Research 8, no. 3 (2002): 325-34. 
Jensen, Bjarne B., and Schnack, Karsten. 'The Action Competence Approach in Environmental Education'. Environmental Education Research 12, no. 34 (2006): 471-86.

Kincheloe, Joe L., McLaren, Peter, and Steinberg, Shirley R. 'Critical Pedagogy, and Qualitative Research: Moving to the Bricolage'. In The SAGE Handbook of Qualitative Research, edited by Norman K. Denzin, and Yvonna S. Lincoln, 163-77. 4th ed. Thousand Oaks: SAGE Publications, $\underline{2011 .}$

Levy, Josh. 'Are You Making a Difference? Values Education for Real Community Change'. Teacher 186, Nov. (2007): 44-7.

Lewis, Elaine, Mansfield, Caroline, and Baudains, Catherine. 'Getting Down and Dirty: Values in Education for Sustainability'. Issues in Educational Research 18, no. 2 (2008): 138-55.

McLaren, Peter. Life in Schools. An Introduction to Critical Pedagogy in the Foundations of Education. 4th ed. Boston: Allyn \& Bacon, 2003.

McLaren, Peter L., and Giarelli, James M. Introduction to Critical Theory and Educational Research, edited by Peter L. McLaren \& James M. Giarelli, 1-22. Albany: State University of New York Press, 1995.

Morgensen, Finn, and Schnack, Karsten. 'The Action Competence Approach and the "New" Discourses of Education for Sustainable Development, Competence and Quality Criteria'. Environmental Education Research 16, no. 1 (2009): 59-74.

Morrow, Raymond A., and Torres, Carlos A. Social Theory and Education: A Critique of Theories of Social and Cultural Reproduction. Albany: State University of New York, 1995.

Payne, Phillip G. 'Moral Spaces, the Struggle for an Intergenerational Environmental Ethics and the Social Ecology of Families: An "Other" Form of Environmental Education'. Environmental Education Research 16, no. 2 (2010): 209-31.

Sarantakos, Sotirios. Social Research. South Melbourne: Macmillan Education Australia, 1993. 
Sorin, Reesa. 'Examining Childhood Through Empowering Lenses'. Every Child 15, no. 3 (2009): 34-5.

UNICEF. 'Convention on the Rights of the Child'. Accessed September 28, 2008. $<$ http://www.unicef.org/crc/index_30167.html>.

Watson, David H. 'Deep Ecology \& Environmental Philosophy: On the Ethics of Crisis and the Crisis in Ethics'. In Against the Megamachine: Essays on Empire \& its Enemies, edited by David H. Watson, 224-43. Brooklyn: Autonomedia, 1997.

Zhao, Guoping. 'The Modern Construction of Childhood: What Does It Do to the Paradox of Modernity?'. Studies in Philosophy and Education 30, no. 3 (2011): 241-56.

Peter Andersen is a lecturer in sustainability education at the University of Wollongong, Australia. Through his research he is seeking ways to empower young people to take on the roles of environmental change agents within their family homes and communities. 